\title{
Some words about the dossier Scales of Global History'
}

DOl: http://dx.doi.org/10.1590/2236-463320161401

\author{
João Paulo Pimenta \\ Universidade de São Paulo, São Paulo - SP, Brasil \\ jgarrido@ usp.br \\ Rafael Marquese \\ Universidade de São Paulo, São Paulo - SP, Brasil \\ marquese@usp.br
}

\section{Abstract:}

This text presents the Scales of Global History dossier, with some reflections about the historiography of Global History.

\section{Resumo:}

Este texto apresenta o dossiê Scales of Global History, com algumas breves reflexões sobre a prática historiográfica da chamada História Global.

Keywords: Global History; Nineteenth century.

Palavras- chave: História Global; Século dezenove; XIX.

From March 3 to 5, 2016, the Faculdade de Filosofia, Letras e Ciências Humanas of the University of São Paulo hosted the International Seminar Scales of Global History, organized by LabM undi-USP as part of activities related to the Global History Network². Its main purpose was to bring together two dozen historians from eight different countries (Brazil, Argentina, Peru, United States, Netherlands, Senegal, India,

\footnotetext{
${ }^{1}$ Translated by Leonardo Marques.

${ }^{2}$ The Global History Network was conceived by Sven Beckert and Marcel van der Linden, and is formed by six institutions: East China Normal University, International Institute of Social History (Netherlands), LabM undi-USP (Brazil), University of Delhi (India), Université Cheikh Anta Diop (Senegal), and Weatherhead Initiative on Global History-Harvard (USA).
} 
and (China), at different stages of their careers, in order to discuss the possibilities and limits of Global History. The papers presented at the seminar explored specific subjects in various times and places, but all of them engaged with broad approaches that could be identified in different ways as global.

During the seminar, the participants explored topics that crossed oceans and united continents such as migratory movements, capital and commodity flows, the shaping of territories, labor dynamics in urban and rural settings, religious and political ideas, among others. Most debates grappled with a central issue: the need to understand certain social realities that by their very historical nature demand from scholars the capacity to use extensive empirical and theoretical tools, thus pushing to move beyond scales of observation that are too restricted.

Many of the papers presented at the seminar - enriched by criticisms and suggestions made by the participants - comprise this special issue of Almanack, a journal that has been eminently cosmopolitan since its inception. None of these articles present an uncritical defense of global approaches, nor do they attempt to define such approaches. The richness of this issue lies precisely in the fact that it presents historical research of the highest quality, which offers the most solid basis for evaluating any theoretical or methodological proposal regardless of its degree of real innovation. In the case of Global History, it seems wise to consider that its potential for innovation depends on the existence of specific - albeit spatially broad - cases in which global approaches prove to be effective and useful.

In addition to their individual historiographical contributions, the articles presented are examples of a Global History that is built upon concrete realities. They are a healthy warning against the possibility that the untapped potential of global approaches could become another shallow theory or simply a new historiographical sect.

Data de recebimento do texto: $29 / 11 / 2016$

Data de aprovação do texto: 30/11/2016 